\title{
A novel mark-recapture-recovery survey using genetic sampling for polar bears Ursus maritimus in Baffin Bay
}

\author{
Stephen N. Atkinson ${ }^{1, *}$, Kristin L. Laidre ${ }^{2,3}$, Todd W. Arnold ${ }^{4}$, Seth Stapleton ${ }^{4}$, \\ Eric V. Regehr ${ }^{2}$, Erik W. Born ${ }^{3}$, Øystein Wiig ${ }^{5}$, Markus Dyck ${ }^{1, \dagger}$, Nicholas J. Lunn ${ }^{6}$, \\ Harry L. Stern ${ }^{2}$, David Paetkau ${ }^{7}$ \\ ${ }^{1}$ Wildlife Research Section, Department of Environment, Government of Nunavut, Igloolik, NU X0A 0L0, Canada \\ ${ }^{2}$ Polar Science Center, Applied Physics Laboratory, University of Washington, Seattle, WA 98105, USA \\ ${ }^{3}$ Greenland Institute of Natural Resources, 3900 Nuuk, Greenland \\ ${ }^{4}$ Department of Fisheries, Wildlife, and Conservation Biology, University of Minnesota, St. Paul, MN 55108, USA \\ ${ }^{5}$ Natural History Museum, University of Oslo, 0318, Oslo, Norway \\ ${ }^{6}$ Environment and Climate Change Canada, University of Alberta, Edmonton, AB T6G 2E9, Canada \\ ${ }^{7}$ Wildlife Genetics International, Nelson, BC V1L 5P9, Canada
}

\begin{abstract}
Changes in sea-ice dynamics are affecting polar bears Ursus maritimus across their circumpolar range, which highlights the importance of periodic demographic assessments to inform management and conservation. We used genetic mark-recapture-recovery to derive estimates of abundance and survival for the Baffin Bay (BB) polar bear subpopulation - the first time this method has been used successfully for this species. Genetic data from tissue samples we collected via biopsy darting were combined with historical physical capture and harvest recovery data. The combined data set consisted of 1410 genetic samples (2011-2013), 914 physical captures $(1993-1995,1997)$, and 234 harvest returns of marked bears (1993-2013). The estimate of mean subpopulation abundance was 2826 (95\% CI $=2284-3367)$ in 2012-2013. Estimates of annual survival (mean \pm SE) were $0.90 \pm 0.05$ and $0.78 \pm 0.06$ for females and males age $\geq 2 \mathrm{yr}$, respectively. The proportion of total mortality of adult females and males that was attributed to legal harvest was $0.16 \pm 0.05$ and $0.26 \pm 0.06$, respectively. Remote sensing sea-ice data, telemetry data, and spatial distribution of onshore sampling indicated that polar bears were more likely to use offshore sea-ice habitat during the 1990s sampling period compared to the 2010s. Furthermore, in the 1990s, sampling of deep fjords and inland areas was limited, and no offshore sampling occurred in either time period, which precluded comparisons of abundance between the 1993-1997 and 2011-2013 study periods. Our findings demonstrate that genetic sampling can be a practical method for demographic assessment of polar bears over large spatial and temporal scales.
\end{abstract}

KEY WORDS: Genetic mark-recapture-recovery - Polar bear - Baffin Bay · Abundance . Survival $\cdot$ Biopsy $\cdot$ Ursus maritimus

\section{INTRODUCTION}

Sea-ice dynamics are rapidly changing across the circumpolar Arctic as a result of climate warming (Meredith et al. 2019), with a trend toward reduced spatial extent and temporal availability of ice. These

${ }^{*}$ Corresponding author: stephen.atkinson@xplornet.com ${ }^{\dagger}$ Deceased changes are expected to have negative impacts on sea-ice-dependent polar bears Ursus maritimus in the long term (Atwood et al. 2015, Molnár et al. 2020). In the near term, the effects of sea-ice loss have been negative in many areas but show variation among subpopulations (e.g. Durner et al. 2018). restricted. Authors and original publication must be credited. 
Some of the earliest impacts on polar bears have been detected in areas where ice melts completely and subsequently reforms each year (Rode et al. 2012, 2014, Stirling \& Derocher 2012, Bromaghin et al. 2015, Lunn et al. 2016, Obbard et al. 2018).

The Baffin Bay (BB) polar bear subpopulation is located between Canada and Greenland (see Fig. 1). Each summer and autumn, when the region is mostly or completely ice-free, the BB subpopulation comes onto land for up to $90 \mathrm{~d}$ (Taylor et al. 2001, Laidre et al. 2020). In BB, the interval between spring sea-ice retreat and fall sea-ice advance has increased by $\sim 12$ d decade $^{-1}$ since 1979 (Stern \& Laidre 2016). This decline in sea-ice habitat has been linked to behavioral and physiological effects on BB polar bears, including longer seasonal periods on land (Laidre et al. 2020), changes in denning phenology (Escajeda et al. 2018), shifting and contracting areas of seasonal use (Laidre et al. 2018a), changes in sea-ice habitat selection (Laidre et al. 2018b), and declines in body condition and reproduction (Laidre et al. 2020). It is unknown whether demographic responses to the changing ice conditions have occurred, similar to those reported for several other polar bear subpopulations (Regehr et al. 2007, Peacock et al. 2012, Bromaghin et al. 2015, Lunn et al. 2016, Aars et al. 2017, Dyck et al. 2017, Obbard et al. 2018)

The abundance of the BB subpopulation was estimated to be 2074 (95\% CI = 1544-2604) bears, based on a physical mark-recapture-recovery study conducted during 1993-1995 and 1997 (Taylor et al. 2005). Taylor et al. (2005) reported relatively high total (i.e. including harvest mortality) survival rates for subadult and adult females and estimated an unharvested population growth rate $(\lambda)$ of $5.5 \% \mathrm{yr}^{-1}$, suggesting relatively strong potential for population growth (Regehr et al. 2017). In the absence of an updated demographic assessment since 1997 (PBSG 1998), and given observed sea-ice declines, population viability analysis (PVA) simulations were used to inform the conservation status of the BB subpopulation, suggesting that the subpopulation was declining in part due to increases in the reported subsistence harvest during the early 2000s (PBSG 2010). Furthermore, Traditional Ecological Knowledge (TEK) studies in Nunavut and Greenland indicated more polar bears being seen near local communities and bears being in poorer body condition (Born et al. 2011a, York et al. 2016), and TEK indicated that the BB subpopulation was concurrently abundant and stable or increasing (Dowsley 2005, 2007). Given large-scale environmental changes, evidence for ecological effects on BB polar bears, concern about harvest levels, and uncertainty associated with PVAs using older data, there was a need to collect new information on subpopulation status.

Under the direction of the Canada-Greenland Joint Commission on Polar Bear, we conducted a 3 yr genetic mark-recapture-recovery study of the BB subpopulation during 2011-2013. A survey plan for the study was developed by Atkinson et al. (2011). This project was part of an inter-jurisdictional initiative to develop less invasive methods to monitor polar bears when logistical, financial, or societal constraints preclude physical handling. Although distance-sampling aerial surveys have emerged as an alternative to physical capture for polar bears, these surveys primarily estimate abundance and do not provide data on subpopulation composition or vital rates, which are needed to evaluate harvest and understand the effects of habitat change (e.g. Aars et al. 2009, Stapleton et al. 2014, 2016, Obbard et al. 2015, 2018, Aars et al. 2017, Dyck et al. 2017). Although genetic mark-recapture is an established method to estimate demographic parameters for wildlife (e.g. Palsbøll et al. 1997, Boersen et al. 2003, Boulanger et al. 2004), it has not been applied to polar bears except in pilot studies (Pagano et al. 2014) and localized investigations (Herreman \& Peacock 2013). Here, we present the first large-scale application of genetic mark-recapture-recovery methods to estimate reproduction, survival, and abundance for a polar bear subpopulation.

\section{MATERIALS AND METHODS}

\subsection{Study area}

Movement data of satellite-collared bears (Taylor et al. 2001), genetic analyses (e.g. Paetkau et al. 1999, Peacock et al. 2015), recaptures, and harvest recoveries of research-marked bears (Taylor \& Lee 1995) have been used to delineate the boundaries of the BB subpopulation. Although some interchange occurs among BB and adjacent subpopulations, including Davis Strait to the south, Lancaster Sound to the northwest, and Kane Basin to the north, the BB subpopulation is considered a distinct demographic unit for management purposes (Taylor et al. 2001, Durner et al. 2018, Laidre et al. 2018a).

The boundaries of the BB polar bear subpopulation encompass an area of $\sim 1$ million $\mathrm{km}^{2}$, including portions of Baffin Island and all of Bylot Island (66.2$73.8^{\circ} \mathrm{N}$ ) in Nunavut (Canada) and parts of West and Northwest Greenland $\left(66.0-77.0^{\circ} \mathrm{N}\right.$; Taylor et al. 
2005) (Fig. 1). BB is ice-covered in winter but typically ice-free in summer (Ferguson et al. 1997). During late spring and summer break-up, sea ice recedes westward from Greenland. The last remnants of ice typically occur off the east coast of Baffin Island. Most polar bears remain on the sea ice as it recedes and then come ashore to spend the iceretreat period on Baffin and Bylot islands (Taylor et al. 2005), although an unquantified but probably small number use coastal northwestern Greenland (Laidre et al. 2018a,b). The east coasts of Baffin and Bylot islands are characterized by high topographic relief and deep, steep-sided fjords, creating difficult conditions to capture or count bears.

\subsection{Study design}

We used information from previous studies of polar bears in BB (e.g. Ferguson et al. 2000, Taylor et al. 2005) and new information obtained via satellite telemetry on the movements and spatial distribution of bears in BB and Kane Basin, collected during the

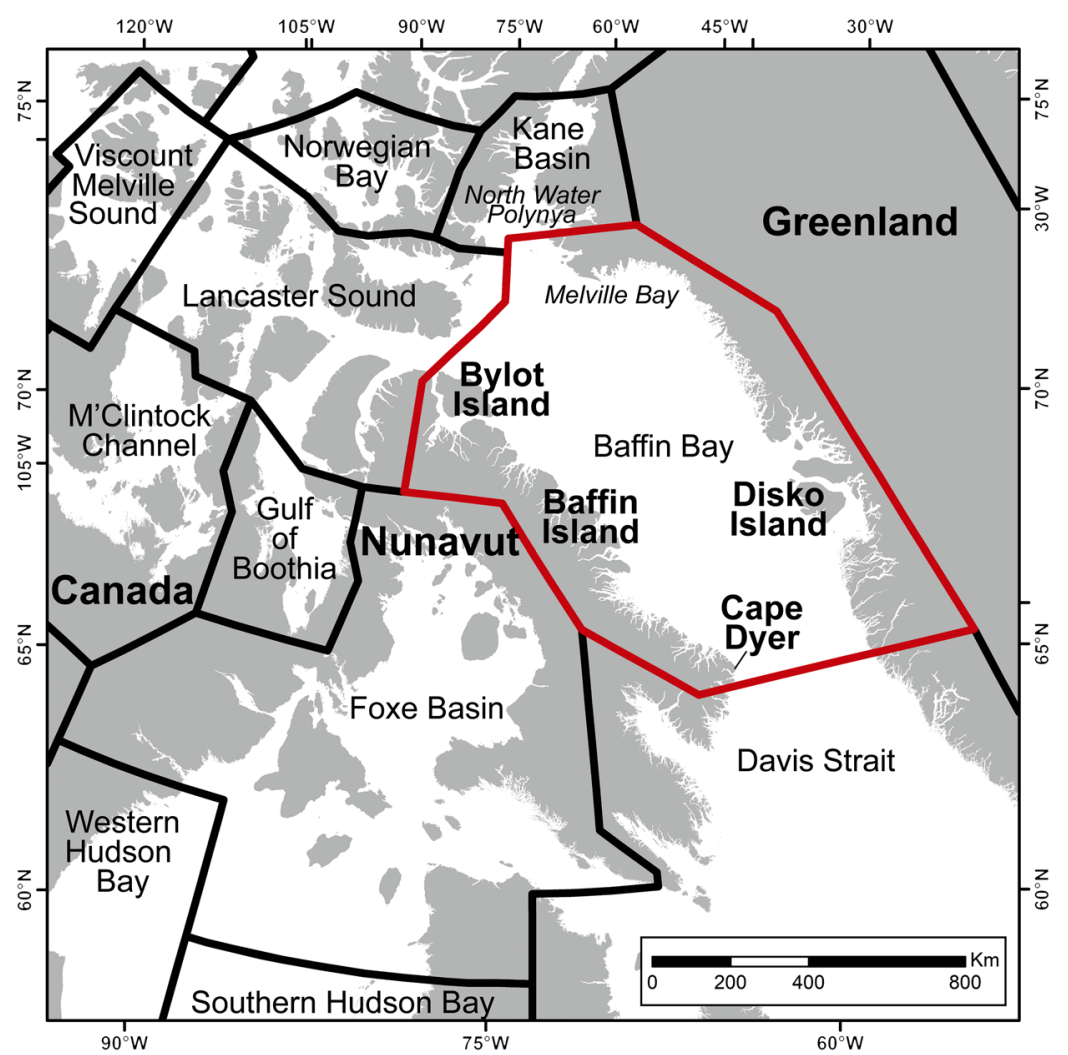

Fig. 1. Boundaries of the Baffin Bay (BB) polar bear subpopulation (red) and surrounding subpopulations (black). The landward boundaries of the BB subpopulation include portions of Baffin Island, Nunavut, Canada, and West Greenland 1990s and 2009-2010, to improve study design and thereby reduce heterogeneity in recapture probabilities that can bias estimates of subpopulation size and demographic parameters (e.g. Nichols et al. 1984, Pollock et al. 1990, Pledger \& Efford 1998, Williams et al. 2002, Fletcher et al. 2012). Due to logistic constraints, sampling during the 1990s was spatially restricted to a portion of the subpopulation's fall range, thus potentially increasing heterogeneity in recapture probabilities (Fig. 2B) (SWG 2016). This pattern was most noticeable in central and northern Baffin Island, where no captures were recorded inland from the mouths of fjords during the entire study period. Although bears are concentrated along the Baffin Island coast during the ice-free season, some individuals travel significant distances inland, move to higher elevations, or remain on offshore ice where access for sampling is difficult (Ferguson et al. 1997, 2000, Taylor et al. 2001, Escajeda et al. 2018, Laidre et al. 2018b).

In contrast to the 1990 s when only one helicopter was involved in sampling, 2 helicopters were used simultaneously in the 2011-2013 operations to improve sampling efficiency. Furthermore, to mitigate recapture heterogeneity in genetic sampling conducted in 2011-2013, we defined sampling strata to guide effort and improve survey coverage and efficiency. Stratification was primarily based on satellite telemetry data obtained from adult female polar bears collared during fall and spring along eastern Baffin Island (1993-1995, 1997) and in spring in W and NW Greenland in 2009 and 2010 (Ferguson et al. 1999, 2000, Born et al. 2011b, 2013). We summarized location data by proximity to the coastline and used the proportion of locations in different inland zones to inform stratification. We delineated a high-density stratum including the coastline and offshore islands, extending $5 \mathrm{~km}$ inland; a moderate-density stratum including inland regions 5-10 km from the coastline; and a low-density stratum extending up to $30 \mathrm{~km}$ inland (Fig. 2A). We attempted to allocate roughly 65, 25, and $10 \%$ of helicopter search effort in the high-, moderate-, and low-density strata, respectively, to efficiently sample the study area. We set a priori guidelines to systematically distribute inland search effort over the entirety of the islands. 

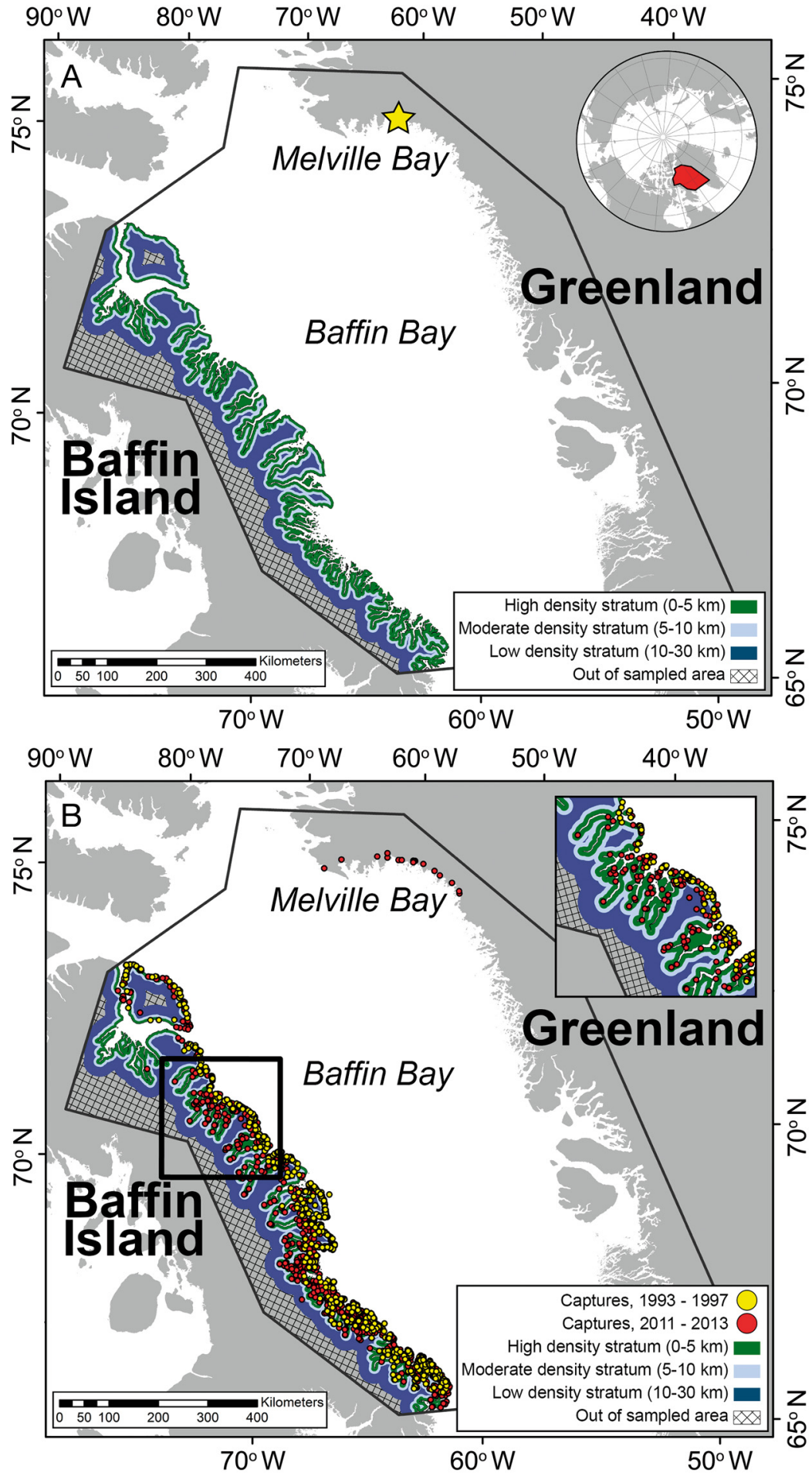

Fig. 2. Boundaries of the Baffin Bay polar bear subpopulation showing (A) sampling strata delineated on Baffin Island, Canada, for genetic mark-recapture-recovery study completed during 2011-2013 and fall sampling in the nearshore regions around Melville Bay, Greenland, (yellow star); (B) locations of polar bears sampled in Baffin Bay during August-October, 1993-1995, 1997 (yellow) and 2011-2013 (red). The region bounded by the black square is enlarged in the inset. Sampling in Greenland in 2011-2013 occurred near Melville Bay. Note the absence of captures in fjords on Baffin Island and in northwestern Greenland during the 1990s
Prior analysis of telemetry data showed that more than half of adult females outfitted with satellite collars were located offshore on remnant sea ice during the fall onshore sampling period in the 1990s (Born \& Dietz 2009, SWG 2016, Laidre et al. 2018b). Polar bears that used offshore sea ice were unavailable for capture due to logistical constraints and, to the extent that individual bears consistently used offshore sea ice throughout the 1990s sampling period, these bears would not have been enumerated. Although it was not feasible to sample bears that may have remained on offshore ice in either decade, sea-ice declines in BB resulted in substantively less offshore ice during the fall in the 2010s relative to the 1990s (Stern \& Laidre 2016). Thus, the presence of bears on offshore ice during the 2011-2013 genetic markrecapture-recovery sampling session was considerably reduced (Laidre et al. 2018b). Additionally, we timed fieldwork to coincide with minimum seaice cover in BB based on Moderate Resolution Imaging Spectroradiometer (MODIS) satellite imagery (https://world view.earthdata.nasa.gov) and Canadian Ice Service maps (AugustOctober in all years). Prior to field work in 2011-2013, we reviewed the locations of collared bears to confirm they had come ashore, and thereby assumed that most bears in the subpopulation were likely concentrated on land and available for sampling.

An unquantified but presumably small number of bears in the BB subpopulation spend the summer and fall in the Melville Bay (Qimmusseriarsuaq) area of Northwest Greenland rather than following the retreating sea ice to Baffin and Bylot islands (Born 1995, Born et al. 2011b, Laidre et al. 2018a,b). To account for this segment of the subpopulation, we extended biopsy sampling to include the Melville Bay area in fall (Fig. 2B). This area was not sampled during the 1990 study (Taylor et al. 2005) because systematic helicopter-based search for 
polar bears during the 1992 and 1993 spring seasons and satellite telemetry indicated that polar bears were not present in the region (Taylor et al. 2001).

We used data collected from 3 separate sources: (1) physical mark-recapture studies in 1993-1995 and 1997 (Taylor et al. 2005), (2) genetic mark-recapture in 2011-2013 (this study), and (3) harvest recoveries of marked bears in 1993-2013. There were no live recaptures of polar bears during the period 1998-2010.

\subsection{Field methods}

Capture, sampling, aging, and data collection protocols for bears marked during 1993-1995 and 1997 are described in Taylor et al. (2005). Genetic markrecapture sampling in 2011-2013 was conducted during the fall (August-October) via remote biopsy darting (Pagano et al. 2014) from helicopters (Bell 206 Long Rangers). In the 2010s, approximately $300 \mathrm{~h}$ of flying time was allocated in Nunavut each year, and 2 helicopters were used (in contrast to operations in the 1990s where one helicopter was used; Taylor et al. 2005). Search effort was distributed according to the a priori stratification (Fig. 2), although we modified sampling on some occasions when terrain or weather conditions limited access. We also biopsied bears in the Melville Bay area of Greenland in September 2012 and 2013 from a helicopter (AS350 Ecureuil B3), allocating $\sim 33 \mathrm{~h}$ of search effort in 2012 and $26 \mathrm{~h}$ in 2013. Coastlines, mountain sides, inland nunataks, glacier fronts, and most offshore islands up to $40 \mathrm{~km}$ from the coast were searched. During field sampling, we did not use telemetry data to locate collared bears.

We collected biopsies of skin and superficial adipose tissue using the Pneu-Dart type C DNA dart (Pneudart). As bears were not chemically immobilized, samples could be safely collected under most situations, including terrain that was steep or near water. Not all cubs-of-the-year (COY) were sampled because of concern of their being injured or separated from their mothers during pursuit. Consequently, we recorded all sightings of COYs during 2011-2013 but only biopsy-darted approximately half of the COYs encountered.

For each bear encountered, we recorded the coordinates using a GPS and noted group size. In the 1990s, sex was determined by physical examination, and age was estimated by counting annular rings in an extracted premolar (Calvert \& Ramsay 1998). In the 2010s, we estimated sex and age-class (i.e. COY, yearling [YRL], subadult [2-4 yr], and adult [ $25 \mathrm{yr}]$ ) from the helicopter at a range of 3-7 $\mathrm{m}$ above ground. Field notes assisted in post hoc reassessment of age-class once sex was confirmed via genetic analysis. When done by experienced observers, this system for estimating sex and age-class appears to be accurate. Amongst a sample of bears of known age and sex, observers without prior knowledge of age or sex were able to correctly classify 97,89 , and $100 \%$ of adult males, solitary adult females, and adult females with dependent offspring, respectively (SWG 2016). Furthermore, the age-class of approximately one-third of biopsy-darted bears was verified based on other encounters during which the individual was captured, or by using genetic identification to assign membership to a known family group.

\subsection{Harvest recoveries}

We used records from subsistence harvest, bears killed in defense of life and property, and other human-caused mortalities in 1993-2010. Dead recoveries of research-marked bears were detected by the return of ear tags or lip tattoos from hunters in Canada and Greenland. Between 2011 and 2013, recoveries were detected by a combination of physical tag returns and genotyping of tissue samples from harvested bears. Although we expected most bears marked in BB to remain within the subpopulation's boundaries, previous studies of tag recoveries in the harvest and satellite telemetry suggest that some bears emigrate (Taylor \& Lee 1995, Taylor et al. 2001, 2005, Laidre et al. 2018a). To account for potential movement to outside of BB (Burnham 1993), tissue samples were genotyped for bears harvested in surrounding subpopulations (e.g. Davis Strait, Lancaster Sound, Foxe Basin, Gulf of Boothia, and Kane Basin). Canada's mandatory harvest reporting system was in place throughout the 1993-2013 study period. Greenland implemented a quota system and made improvements to the reporting system in the mid-2000s and instituted a mandatory harvest reporting system in 2012 for collection of a tissue sample and premolar tooth for age determination (Anon 2018).

\subsection{Recaptures of marks from earlier sampling sessions}

To identify bears physically captured during the 1990s that were subsequently encountered during the genetic mark-recapture sampling from 20112013, we genotyped tissue samples from all bears 
sampled in the 1990s except for bears that were harvested between 1993 and 2011, bears whose known or estimated age would have been $>35$ yr in 2011 and thus almost certainly would be dead, and 33 bears that lacked tissue samples. In total, the data included 650 individuals marked in the 1990s that would have been $\leq 35 \mathrm{yr}$ old and had not been harvested by the time genetic sampling began in 2011. During mark-recapture-recovery modeling, the 33 bears lacking tissue samples were assigned a recapture probability of 0 in 2011-2013 (see below).

\subsection{Genetic analysis}

Samples were stored dried, frozen, in ethanol or dimethyl sulfoxide and subsequently sent to Wildlife Genetics International for analysis. DNA was extracted from tissue with QIAGEN DNeasy Blood and Tissue Kits (www.qiagen.com) (see also Text S1 in the Supplement at www.int-res.com/articles/suppl/ n046p105_supp.pdf). Analysis of individual identity followed a 3 phase protocol previously validated for bears and described in Paetkau (2003) and Kendall et al. (2009). To select markers for the analysis of individual identity, we used allele frequency data from 1771 polar bears for which complete 20 locus genotypes existed before the genetic mark-recapture study began (Government of Nunavut unpubl. data). We ranked the 20 microsatellite markers in the data set by expected heterozygosity. The 8 most variable markers that could be analyzed together in a single sequencer lane were selected for use (see Text S1). These surpassed the required standard for marker variability (Paetkau 2003). In addition to the 8 microsatellite markers, we analyzed sex on every sample using a $Z F X / Z F Y$ marker. We searched the data set for genotype matches that seemed unlikely based on our field observations and records. In each case, 3 extra markers were added to the genotypes to lower the probability of chance matches between individuals $(G 1 D, G 10 J, G 10 L)$. The extra loci confirmed all of these matches. Once the genotyping and errorchecking were complete, we assigned an individual identity for each unique 9 locus genotype (see Text S1, Fig. S1).

\subsection{Statistical analysis}

We used the Burnham (1993) model in Program MARK (White \& Burnham 1999) to analyze joint liverecapture and dead-recovery data from the $21 \mathrm{yr}$
(1993-2013) study period in BB. We estimated survival probability $\left(S_{i}\right.$ the probability of surviving interval $t$ to $t+1)$, recapture probability ( $p$; the probability of live-recapturing a marked animal), dead reporting probability $(r$; the probability that a bear that died during interval $t$ to $t+1$ was killed by humans and reported to authorities), and fidelity ( $F_{\text {; }}$ the annual probability that a bear does not permanently emigrate from the sampling area and is therefore available for recapture in future years). The inclusion of dead recoveries allowed for estimation of true survival (i.e. a biological survival rate that does not include permanent emigration). Furthermore, harvest recovery data increased information on the fate of individual bears, decreased susceptibility to bias because the sampling mechanism for dead recoveries was different from live recaptures, and allowed estimation of survival between the 2 liverecapture periods (Peacock et al. 2012).

We identified an a priori set of model structures (i.e. sub-models) for each parameter $(S, p, r$, and $F$ ) in the Burnham model. For $S$, all sub-models included 2 age classes because we expected that dependent offspring (COY and YRL) would have lower survival than age 2+ bears (Table S1). Previous studies have estimated survival separately for COY versus YRL (e.g. Regehr et al. 2007), but we set COY and YRL survival equal because small sample sizes led to nonidentifiable survival estimates for COY (i.e. $S \approx 1$ ). We also combined subadult and adult bears into a single age class (age $2+$ ) because we could not reliably distinguish subadults from adults during aerial tissue sampling. We hypothesized that $S$ would differ by sex for age 2+ bears because harvest in BB is selective for males, so we included a sex effect on age $2+$ survival in all models. We evaluated 3 submodels that considered different temporal variation in survival for age $2+$ male and female bears: (1) constant survival across years, (2) unique survival estimates within each sampling period (i.e. 1993-1997, 1998-2010, and 2011-2013) with an additive sex effect such that males and females had parallel temporal patterns, or (3) survival varying among sampling periods independently for age $2+$ males versus females. Although we originally intended to include covariates related to annual ice conditions on both survival and recapture probabilities (e.g. Lunn et al. 2016), the limited number of sampling occasions precluded estimation of annual relationships between model parameters and environmental conditions.

We considered 9 candidate structures for $p$ (Table S2). Recapture probabilities for COY and YRL were the same as for age $2+$ females because they 
could only be observed with their mothers. We hypothesized that $p$ of age $2+$ males would differ due to spatial segregation of bears onshore by sex and age classes (Taylor et al. 2005) and used this 2 group structure (i.e. family including age 2+ females and dependent young vs. age $2+$ males) in all sub-models for $p$. We evaluated 2 structures for temporal variability in $p$ : (1) given differences in sampling protocols, search effort, and survey teams between the 1990s and 2000s, $p$ was allowed to differ between the 2 intensive sampling periods, considering both additive and interactive effects with family; and (2) a time-dependent structure for $p$ (i.e. allowing for yearto-year variability) with an additive effect for family, given that both sampling effort and environmental conditions (e.g. sea-ice extent, which could affect presence in the sampling area) varied substantially among years. In all sub-models, $p$ was fixed to 0 in 1996 and 1998-2010 when no live-encounter sampling occurred.

Exploratory analyses suggested that proximity to the coastline at first capture also may explain variability in $p$. Specifically, contingency tables suggested that bears initially captured inland were more likely to be recaptured inland; and conversely, that bears initially captured near the coast were more likely to be recaptured in coastal regions. We created a binary geographic covariate based on an individual's first capture location (coastline), using a threshold of $2 \mathrm{~km}$ from a smoothed coastline excluding deep fjords. We considered sub-models in which coastline effects differed between the 2 intensive sampling periods and in which coastline was used for 2010s sampling only, given that exploratory analyses suggested this effect was stronger in the 2010s.

Some adult female bears were fitted with satellite collars during 1992-1997 (Ferguson et al. 1997, Taylor et al. 2001). As Taylor et al. (2005) stated that the locations of collared bears were known and this information was used to relocate animals in 1994, 1995, and 1997, we constructed 3 binary radio covariates (rad94, rad95, rad97) to identify when radioed females were wearing functional collars and therefore more susceptible to recapture, and we included this covariate in all models. Dependent offspring were assigned the same covariate value as their mother.

As dead recoveries were more limited than live encounters, we considered a single model structure for $r$ in which reporting probability differed among COY, YRL, age 2+ females, and age 2+ males due to regulatory prohibitions on the harvest of females with dependent offspring and sex-selective harvest quotas. However, we did not fix $r=0$ for COY because at least one was harvested during the study period. We also hypothesized that improvements in the Greenlandic reporting system during the mid2000s might affect reporting rates (e.g. Born et al. 2011a) by allowing $r$ to differ between 1993-2005 and 2006-2013. Since few COY or YRL were harvested, this temporal structure was included as an additive effect for age $2+$ bears only.

We considered 3 candidate structures for F. Previous studies (Taylor et al. 2005) assumed perfect overlap between the areas in which live encounters and dead recoveries occurred. To reflect this assumption, we considered a sub-model with $F$ fixed to 1 for all sex- and age-classes, without assessing a parameter penalty for Akaike's information criterion adjusted for overdispersion and small sample size $\left(\mathrm{QAIC}_{\mathrm{c}}\right)$. Under this approach, any permanent emigration from the BB subpopulation would be reflected in lower estimates of $S$. Given that the subpopulation boundaries are only partially discrete, interchange is known to occur among subpopulations, and some harvest recoveries occurred outside the BB population boundaries (Laidre et al. 2018a), we also fit models that allowed for permanent emigration. We considered 2 additional structures, one with a timeconstant $F$ across all 4 sex- and age-classes and another where $F$ differed between age 2+ males and other bears.

To estimate overdispersion (i.e. extra-binomial variation), we used the median $\hat{c}$ approach in Program MARK with the most parameterized model (Cooch \& White 2015). Results suggested modestly over-dispersed data (i.e. $\hat{C}=1.1$ ), as would be expected given the dependency between females and their cubs (Taylor et al. 2005), so we based model selection and inference on QAIC $_{c}$ using this value of $\hat{c}$ (White \& Burnham 1999).

The 3 sub-models for $S, 9$ for $p, 1$ for $r$, and 3 for $F$ resulted in 81 potential model structures under an all-combinations approach. We used a modified version of the plausible combinations approach (Bromaghin et al. 2013) to limit the size of the candidate model set for model averaging. This process entailed holding constant the most generalized structure (i.e. most complex) for 3 of the 4 sub-models while evaluating alternate structures for the fourth. During this process, we considered sub-model structures with $\Delta$ QAIC $_{\mathrm{c}}<4$ as representing plausible alternatives and subsequently constructed all possible model combinations from these sub-models.

We computed model-averaged parameter estimates using all models with $\Delta$ QAIC $_{\mathrm{c}}<4$ (Burnham \& 
Anderson 2002). Assuming that marks of all harvested bears were identified and reported, we estimated harvest probability $(\hat{h})$ as the product of reporting and interval mortality probabilities: $\hat{h}=$ $\hat{r}(1-\hat{S})$, with variance estimated using the delta method:

$$
\begin{aligned}
& \operatorname{var}(\hat{h})=\operatorname{var}(\hat{r})(1-\hat{S})^{2}+\hat{r}^{2} \operatorname{var}(\hat{S}) \\
& +2 \operatorname{cov}(\hat{r}, \hat{S}) \hat{r}(1-\hat{S})
\end{aligned}
$$

for each unique combination of $\hat{r}$ and $\hat{S}$. Assuming temporal separation of harvest and natural mortality, natural survival can then be estimated as: $\hat{S}_{\mathrm{n}}=\hat{S}-\hat{h}$, with variance approximated by

$$
\begin{aligned}
& \operatorname{var}\left(\hat{S}_{\mathrm{n}}\right)=\operatorname{var}(\hat{S})(1-\hat{r})+\operatorname{var}(\hat{r})(1-\hat{S})^{2} \\
& +2 \operatorname{cov}(\hat{S}, \hat{r})(1-\hat{S})(1-\hat{r})
\end{aligned}
$$

(Taylor et al. 2005, Peacock et al. 2013). We estimated abundance for YRL and age 2+ bears using a generalized Horvitz-Thompson estimator,

$$
\hat{N}_{i, t}=\frac{\mathrm{n}_{i, t}}{\hat{p}_{i, t}},
$$

where $\mathrm{n}_{i, t}$ is the number of bears encountered in group $i$ during year $t$ and $\hat{p}_{i, t}$ is the estimated recapture probability for group $i$ during year $t$. Counts of $n$ did not accurately represent COY because we did not biopsy all COY during the 2011-2013 sampling period. Thus, we estimated COY abundance as the product of abundance of age $2+$ females with COY litters, estimated via a Horvitz-Thompson estimator, and mean observed COY litter size. We summed estimates of abundance across groups to estimate total bears by year. Similar to earlier studies (e.g. Taylor et al. 2005, Peacock et al. 2013), we employed the delta method (Seber 1982, Powell 2007) to estimate variances for annual abundance estimates using the 'emdbook' package (Bolker 2016) in R version 4.1.0 (R Development Core Team 2021). Variance estimates incorporated parameter variances and covariances, as computed in Program MARK, as well as variances of mean COY litter sizes. We used model weights to model average estimates of total abundance and their associated variances by year. We also estimated mean total abundance for each intensive sampling period. Given the $13 \mathrm{yr}$ interval without live captures preceding 2011, estimates of abundance for 2011 were based on estimates of $p$ reflecting the small number of bears that were marked during the 1990s and survived until 2011. These estimates of $p$ were characterized by high uncertainty, which resulted in low precision of the Horvitz-Thompson estimator in 2011 (CV = 0.42) compared to the other 5 years (mean $\mathrm{CV}=0.18$ ). Therefore, we excluded the less-reliable estimate of abundance from 2011 when calculating mean total abundance for the 2010s. We estimated the standard error of mean total abundance as

$$
\mathrm{SE}=\sqrt{ }\left[\sum_{i} \sigma_{i}^{2} / \mathrm{n}^{2}\right],
$$

where $\sigma_{i}^{2}$ is the variance of abundance in year $i$ and $\mathrm{n}$ is the number of years (3 for 1990s, 2 for 2010s).

\subsection{Geographic sub-setting to evaluate effects of differing sampling schemes}

Sampling during the 1990s was spatially restricted to a portion of the BB subpopulation's fall range and did not include bears located farther inland, particularly within deep fjords or on the sea ice (Taylor et al. 2005). In contrast, onshore sampling from 2011-2013 was more comprehensive and systematic, and there was little or no offshore sea ice for bears to use in the fall. Although we had capture locations from the 1990s, flight paths of the helicopter used to capture bears in the 1990s were unavailable. Therefore, we approximated the extent of the sampling area in the 1990s based on capture locations. We then created a subset of the 2010s live-capture data that only included captures occurring within the estimated 1990s sampling area, recompiled individual capture histories, and repeated mark-recapture analyses using the same procedures as outlined above. We expected that a comparison of abundance estimates between sampling periods for the geographically restricted sampling area would approximate the temporal changes in abundance for the entire sampling area. Conceptually, this assumed that a similar proportion of bears inhabited the excluded survey areas during each sampling period. This assumption seemed plausible and was supported by analyses of satellite telemetry data indicating the onshore distribution (relative to the coastline) of polar bears did not vary between the 1990s and 2010s (SWG 2016). Although this investigation provides insight into the potential effects of differences in onshore sampling between the 2 intensive study periods, it did not provide any information on potential bias in the 1990s abundance estimate due to bears using offshore sea ice.

\section{RESULTS}

Genetic sampling in BB during 2011-2013 yielded genotypes for 1190 bears, of which 220 were recaptured (including 42 bears marked in BB in the 1990s). 
Eleven biopsy samples $(\sim 1 \%)$ failed to yield sufficient DNA for genotyping due to limited tissue availability. The combined BB mark-recapture-recovery data set for the period 1993-2013 consisted of 2324 encounters of 1992 individuals, and 234 dead recoveries (Table S3). During September 2012 and 2013, we sampled 30 polar bears (of which 21 were independent bears) in Melville Bay, NW Greenland (cf. 1043 total captures in the BB subpopulation during 2012 and 2013; Table S3), consistent with previous information that a relatively low number of bears reside in Greenland during the summer.

We identified 1, 2, 3, and 1 plausible sub-models for $S, p, F$, and $r$, respectively (Tables S4-S6), resulting in $1 \times 2 \times 3 \times 1=6$ candidate models. In the mostsupported model, young bears (COY + YRL) had constant survival whereas survival of older (age 2+) bears varied independently by sex among the 3 sampling periods; $p$ varied by year with age $2+$ males and age 2+ females (and dependent offspring) exhibiting parallel patterns through time; $r$ varied across 3 age classes, with age $2+$ bears exhibiting variation by sex and time period; and $F$ was constant across all sex and age classes. Two additional model structures were within $\Delta \mathrm{QAIC}_{\mathrm{c}}=4$ of the most-supported model, including a model with $F$ estimated separately for independent males and a model with $F$ fixed to 1 (Table 1).

Survival of age $2+$ females was lowest in the first sampling period and increased thereafter, whereas survival for age $2+$ males was highest in the first sampling period and declined thereafter, especially in the final sampling period (Table 2). Harvest mortality and reporting rates were nearly 2 -fold higher for age $2+$ males than age $2+$ females but were similar before and after 2005 (Table 2). The point estimate of natural survival for age $2+$ males (mean \pm SE: $0.83 \pm 0.06$ ) was less than age $2+$ females $(0.91 \pm 0.05)$ during 2011-2013. Model-averaged estimates of site fidelity estimated that approximately $3-4 \%$ of the study population permanently emigrated from the sampling area each year. The estimates of $F$ were $0.96 \pm 0.03$ for COYs, YRLs, and age 2+ females and $0.97 \pm 0.02$ for age $2+$ males.

Table 1. Results for models with Akaike's information criterion adjusted for overdispersion and small sample size $\left(\Delta Q A I C_{c}<4\right)$ from analysis of mark-recapture-recovery data from the Baffin Bay polar bear subpopulation, 1993-2013. Young = cubs-ofthe-year (COY) and yearlings (YRL); $2+=$ bears aged 2 yr and older; sex = male vs. female (age $2+$ bears only). For $S$, epoch $=$ periods defined by sampling method (1993-1997, 1998-2010, and 2011-2013). For $p$, family = age 2+ females and any associated young versus age $2+$ males; and $t=$ full time variation. For $r$, time $=1992-2005$ vs. 2006-2013. All $p$ structures incorporated the radio collar covariate representing bears that were outfitted with collars that may have been used to locate them

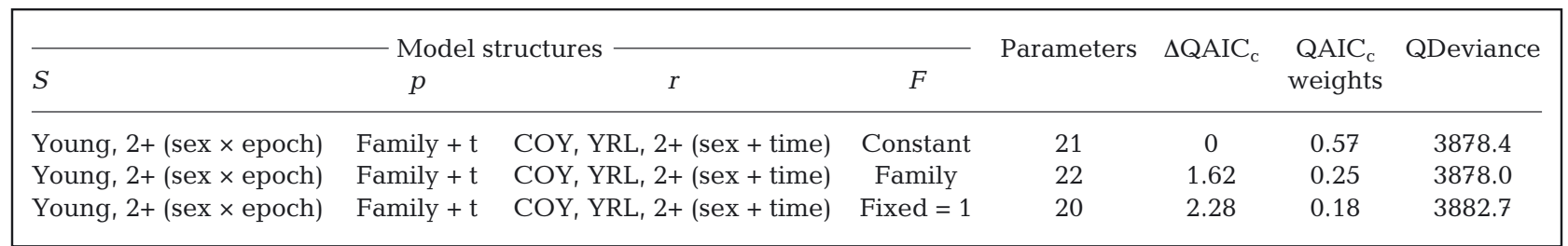

Table 2. Model-averaged estimates and standard errors (SE) of Seber reporting $(r)$, harvest $(h)$, total survival $(S)$, and natural survival $\left(S_{\mathrm{n}}\right)$ probabilities from polar bears in the Baffin Bay subpopulation, 1993-2013, based on candidate models in Table 1. Although cubs-of-the-year (COY) and yearlings (YRL) reporting and survival probabilities were estimated as constant over all years of the study (labeled 'All'), we could only estimate these parameters in years when COY and YRL were actually marked (e.g. 1993-1997, 2011-2013)

\begin{tabular}{|lcccccccrc|}
\hline Age & Years & $r$ & SE & $h$ & SE & $S$ & SE & $S_{\mathrm{n}}$ & SE \\
\hline COY & All & 0.061 & 0.052 & 0.008 & 0.009 & 0.871 & 0.059 & 0.879 & 0.061 \\
YRL & All & 0.130 & 0.074 & 0.017 & 0.016 & 0.871 & 0.059 & 0.888 & 0.062 \\
$2+$ F & $1993-1997$ & 0.186 & 0.045 & 0.029 & 0.012 & 0.841 & 0.040 & 0.870 & 0.040 \\
& $1998-2005$ & 0.186 & 0.045 & 0.010 & 0.005 & 0.945 & 0.022 & 0.955 & 0.021 \\
& $2006-2010$ & 0.154 & 0.052 & 0.008 & 0.005 & 0.945 & 0.022 & 0.953 & 0.021 \\
& $2011-2013$ & 0.154 & 0.052 & 0.016 & 0.013 & 0.894 & 0.053 & 0.910 & 0.053 \\
$2+$ M & $1993-1997$ & 0.298 & 0.032 & 0.033 & 0.007 & 0.891 & 0.020 & 0.923 & 0.018 \\
& $1998-2005$ & 0.298 & 0.032 & 0.038 & 0.008 & 0.872 & 0.019 & 0.910 & 0.017 \\
& $2006-2010$ & 0.253 & 0.055 & 0.032 & 0.008 & 0.872 & 0.019 & 0.905 & 0.016 \\
& $2011-2013$ & 0.253 & 0.055 & 0.057 & 0.027 & 0.774 & 0.061 & 0.831 & 0.062 \\
\hline
\end{tabular}


Mean estimates of total abundance for the BB subpopulation were 2173 (95\% CI = 1641-2704) during 1994-1997 and 2826 (95\% CI = 2284-3367) during 2012-2013 (Table 3). The geographic subset of data that included similar sampling areas in the 1990s and 2010s included live observations of 1679 individuals, as 313 bears from the 2010s were censored from the analyses based on capture locations outside the estimated sampling frame of the 1990s. Model selection results and parameter estimates for the geographic subset were generally similar to the comprehensive data set (Tables S7 \& S8). There was no statistically significant difference in mean estimates of abundance using the geographic subset data: 2326 (95\% $\mathrm{CI}=1788-2864)$ during 1994-1997 versus 2553 (95\% $\mathrm{CI}=1953-3153)$ during 2011-2013.

\section{DISCUSSION}

This is the first large-scale genetic mark-recapture-recovery study of polar bears and demonstrates the utility of this method for this species.

The 2012-2013 point estimate of abundance from the full data set was $\sim 30 \%$ higher than the 1990s point estimate, but this difference decreased to $\sim 10 \%$ when we used a spatial subset of our recent data that more closely matched the sampling frame from the 1990s. This finding suggests that the apparent increase in abundance between time periods based on the entire data set was to a large extent due to the increased geographic distribution of sampling effort in the 2010s (Table 3). Differences in sampling protocols and changes in environmental conditions between epochs make interpretation about true changes in population size difficult. Most notably, the distribution of capture locations was different between sampling periods, with a higher proportion of captures in inland areas and deep within fjords during the 2010s (Fig. 2). When we examined satellite telemetry data from companion studies to compare on-land distribution and summer habitat use between the 2 sampling periods, we found no evidence for changes in on-land distribution between the 2 sampling periods, suggesting that differences in the spatial distribution of captures resulted from a more restricted sampling frame in the 1990s (SWG 2016). If some individual bears were consistent in their use of fjords between years, then these individuals would have had capture probabilities near 0 in the 1990 s, leading to underestimates of total population size (White \& Cooch 2017).

The presence of offshore sea ice during the 1990s was another potential source of negative bias in abundance estimates because bears using offshore sea ice were either temporarily or permanently absent from the mark-recapture sampling area during the 1990s. In contrast, during the 2010s, sea ice was largely absent from $\mathrm{BB}$ in late summer and bears were more concentrated in the onshore sampling areas (i.e. on Baffin or Bylot islands or West Greenland) (Laidre et al. 2018b). Although sample sizes were small, telemetry data provide some insight into the potential magnitude of this sampling problem. In the 1990 s, only $\sim 22 \%$ of collared bears were inside of the sampled area (SWG 2016); the remainder were on remnant sea ice offshore or on land outside the sampled area and therefore unavailable for capture.

By comparison, during 2011-2013, 73\% of collared bears were inside the sampling area (SWG 2016). If the probability of being a temporary emigrant in the 1990s was sufficiently high, relative to

Table 3. Model-averaged (difference in Akaike's information criterion adjusted for overdispersion and small sample size $\left[\Delta \mathrm{QAIC}_{\mathrm{c}}\right]<4$ ) estimates of abundance (mean, SE, CV, and $95 \%$ lower and upper confidence intervals [LCI and UCI]) obtained from mark-recapture-recovery study of polar bears in the Baffin Bay subpopulation using the full data set and geographic subset, 1994-1997, 2011-2013. The 2011 estimate is believed to be biased based on a limited sample of surviving bears from the 1990 s that were recaptured in 2011

\begin{tabular}{|c|c|c|c|c|c|c|c|c|c|c|}
\hline \multirow[b]{2}{*}{ Years } & \multirow[b]{2}{*}{ Mean } & \multirow[b]{2}{*}{$\mathrm{SE}$} & \multirow{2}{*}{$\begin{array}{l}\text { Full data } \\
\text { CV }\end{array}$} & \multirow[b]{2}{*}{ LCI } & \multirow[b]{2}{*}{ UCI } & \multirow{2}{*}{ Mean } & \multirow{2}{*}{$\begin{array}{c}-\mathrm{G} \\
\mathrm{SE}\end{array}$} & \multirow{2}{*}{$\begin{array}{l}\text { aphic } \\
\text { CV }\end{array}$} & \multirow{2}{*}{ LCI } & \multirow[b]{2}{*}{$\mathrm{UCI}$} \\
\hline & & & & & & & & & & \\
\hline 1994 & 2280 & 615 & 0.27 & 1073 & 3486 & 2545 & 597 & 0.23 & 1375 & 3715 \\
\hline 1995 & 1999 & 359 & 0.18 & 1295 & 2703 & 2208 & 382 & 0.17 & 1459 & 2957 \\
\hline 1997 & 2239 & 393 & 0.18 & 1469 & 3009 & 2225 & 418 & 0.19 & 1406 & 3044 \\
\hline 1994-1997 & 2173 & 271 & 0.12 & 1641 & 2704 & 2326 & 274 & 0.12 & 1788 & 2864 \\
\hline 2011 & 4202 & 1762 & 0.42 & 749 & 7656 & 2516 & 1473 & 0.59 & -371 & 5403 \\
\hline 2012 & 2595 & 352 & 0.14 & 1905 & 3286 & 2447 & 423 & 0.17 & 1618 & 3276 \\
\hline 2013 & 3056 & 426 & 0.14 & 2221 & 3893 & 2659 & 442 & 0.17 & 1793 & 3525 \\
\hline $2012-2013$ & 2826 & 276 & 0.10 & 2284 & 3367 & 2553 & 306 & 0.12 & 1953 & 3153 \\
\hline
\end{tabular}


the short duration of the study and small sample sizes, or if there was Markovian dependence in the probability of being a temporary emigrant (e.g. if a bear that was on remnant sea ice in year $t$ tended to return to the ice in year $t+1$ ), then abundance estimates from the 1990s may be subject to additional bias. Given the multiple potential sources of negative bias in the 1990s abundance estimate and statistical uncertainty in estimated parameters, we cannot accurately assess trends in the size of the BB subpopulation between the 1990s and 2010s.

Temporary emigration also has the potential to affect estimates of survival probability, especially during the terminal years of our study (Peñaloza et al. 2014), although these issues are mitigated to some extent by the inclusion of dead recovery data (Peacock et al. 2012). Our point estimates of survival for age 2+ females in 1993-1997 were lower than estimates of similar age classes obtained by Taylor et al. (2005) and Peacock et al. (2012), but our estimates of COY and yearling survival were higher. Factors that may contribute to these differences include (1) different treatment of age classes, necessitated by our inability to age tissue-sampled bears using cementum annuli; (2) Taylor et al. (2005) modeled initial captures (but not recaptures) resulting from opportunistic live-capture studies in the 1970s and 1980s, which we excluded because these data were not from a designed study to estimate demographic parameters; and (3) the inclusion of additional information (e.g. harvest recoveries during the 2000s and live captures during the 2010s), given that some parameters were estimated using information that was shared across sampling epochs.

The mean estimate of total annual survival of age $2+$ males was particularly low $(0.78 \pm 0.06)$ during 2011-2013 compared to values from earlier periods in this study and values reported for most other polar bear subpopulations (PBSG 2010). Although $r$ for age $2+$ males was higher than age $2+$ females due to male-biased harvest, estimates of unharvested male survival 2011-2013 $\left(S^{*}=0.83\right)$ were also significantly lower than estimates of $S^{*}$ for females during this period $\left(S^{*}=0.91\right)$. Low survival of adult males in the 2010s may be a biological signal that reflects a disproportionate impact of environmental change on males, either through lower true survival or increased emigration of young males to adjacent subpopulations. However, interpretation of point estimates and potential trends in $S$ is difficult due to the short time-frame (i.e. only 3 yr) of live recaptures in the 2010s, confounding of parameters, and potential bias in estimates of survival during terminal years (e.g. Peñaloza et al. 2014). We suggest that, when viewed together with information on habitat loss (Stern \& Laidre 2016, Laidre et al. 2018b) and declining body condition (Rode et al. 2012), low estimates of $S$ for age 2+ males in 2011-2013 may signal negative density-dependent population effects. However, we emphasize that additional years of encounter data would be necessary to determine the degree to which low estimates of survival were influenced by temporary emigration or other factors. Regehr et al. (2018) modeled movement with respect to the sampling area for the Chukchi Sea polar bear subpopulation using an integrated population model that combined mark-recapture and telemetry data. Application of similar methods in future demographic analyses for the BB subpopulation may help evaluate the effects of temporary emigration on parameter estimates.

Adjusting total survival with $r$ to derive unharvested survival yielded estimates of female survival in the 2010s $\left(S^{*}=0.91\right)$ that appear too low to support stable or positive population growth in the absence of harvest. Regehr et al. (2015) suggested that a minimum unharvested adult female survival rate of $\sim 0.93$, referenced to a population density at maximum net productivity level, is necessary for long-term persistence. Due to the lack of precise numeric age information available from non-invasive genetic sampling in the 2010s, we estimated survival for a single age class of polar bears age $\geq 2 \mathrm{yr}$. Under this approach, subadult and senescent bears, which likely have lower survival rates (e.g. Regehr et al. 2007), were included with prime age adults. This likely had the effect of reducing the overall estimate of female survival. These considerations, in conjunction with effects of temporary emigration, could have led to negative bias in estimates of female survival (Peñaloza et al. 2014).

Although there are uncertainties in the BB subpopulation related to the demographic analyses, additional sources of information are useful for informing current subpopulation status. The BB subpopulation has responded to an ongoing loss of sea-ice habitat through changes in range, movements, habitat selection, body condition, and reproductive performance (e.g. Peacock et al. 2012, Rode et al. 2012, SWG 2016, Escajeda et al. 2018, Laidre et al. 2018a,b). These signs point to a subpopulation that could be exhibiting density-dependent effects associated with declining environmental carrying capacity, or negative density-independent demographic effects associated with shorter on-ice periods during which polar bears can access their seal prey. The relatively low esti- 
mates of unharvested survival for the 2010s, especially for adult males, are consistent with this explanation, although as stated previously we cannot rule out the presence of terminal bias in our survival estimates. A reanalysis after additional harvest data have accumulated would be useful in this regard.

Reduced survival amongst subadult polar bears has been predicted and observed to be one of the first demographic responses to sea-ice habitat loss (Regehr et al. 2007, Stirling \& Derocher 2012). We did not estimate survival separately for subadults and adults due to inability to accurately distinguish between these age classes during biopsy darting. However, evidence suggests that experienced observers can reliably distinguish between subadult and adult polar bears using a combination of field assessments and genetic information (i.e. sex) obtained from biopsy darting (SWG 2016). Future modeling of data from genetic mark-recapture studies could therefore consider a more detailed age structure than was used in our study. Alternatively, analytical methods such as mark-recapture models with state uncertainty (Pradel 2009) could also be used to model the relatively low occurrence of errors in the estimation of age class. Employing a more detailed age structure could help to assess whether survival rates for adults and subadults exhibited different temporal trends.

\section{MANAGEMENT IMPLICATIONS}

This is the first abundance estimate for a polar bear subpopulation to be derived using genetic mark-recapture. Using biopsy darting, we were able to sample a large number of bears (1190 individuals) under conditions that were sometimes unsuitable for physical capture and handling. Our study demonstrates the utility of this method for application at large spatial and temporal scales for monitoring subpopulation status. Where logistical or other constraints preclude physical capture programs, this less invasive method is a practical alternative. We note, however, that physical capture remains the preferred method for obtaining detailed vital rate data, including age structures that cannot be derived from genetic sampling. Furthermore, deployment of satellite collars on adult females, which required physical capture in Greenland during the study period, provided critical information for interpreting abundance and vital rates and providing management advice (Laidre et al. 2018a,b, 2020). Additionally, physical capture allows for collection of auxiliary data and samples to support a range of studies related to bear health (e.g. Bechshøft et al. 2011, Patyk et al. 2015), energetics (e.g. Pagano et al. 2018), physiology (e.g. Whiteman et al. 2015, Rode et al. 2018), body condition (e.g. Obbard et al. 2016), and diet (e.g. Galicia et al. 2015), all of which are essential for understanding this species' adaptability to environmental change.

The potential challenges in interpreting long-term trends in abundance and survival are evident in our study. Challenges in deriving estimates of vital rates were largely the result of sampling design rather than sampling method. With appropriate sampling design, genetic mark-recapture-recovery should be capable of yielding reliable estimates. Although Taylor et al. (2005) and York et al. (2016) reported that the BB subpopulation was uniformly and comprehensively sampled during the 1990s, we quantified differences in the sampled area between epochs. These differences precluded an assessment of trends in abundance, and the $13 \mathrm{yr}$ interval between livecapture sessions limited our ability to assess temporal trends in survival and likely resulted in increased individual heterogeneity in survival (which we could not explicitly model), as newly marked bears in the 2010s were pooled with older individuals first marked in the 1990s. Recent analyses of mark-recapturerecovery data for polar bears have identified the limitations of model-based methods to account for inconsistent sampling or violated modeling assumptions (e.g. Bromaghin et al. 2015).

We recommend that complete and consistent sampling of the study area is necessary for accurate assessment of subpopulation status and suggest considering a robust design (i.e. multiple secondary sampling sessions per autumn) if unbiased estimates of abundance are a primary objective (e.g. Converse et al. 2009). A priori analyses could evaluate the effects of design modifications such as increasing (or decreasing) sample sizes, additional consecutive years of live-capture sampling, shorter intervals between live-capture sampling, or incorporating additional dead recoveries after 2013 (Peacock et al. 2012). From an analytical perspective, capturerecapture models that allow for temporary emigration could mitigate potential bias associated with movements in and out of the sampling area (Schaub et al. 2004), and integrated population models that include mechanistic links between vital rates and abundance (Regehr et al. 2018) could provide a more complete assessment of population dynamics and increase power to evaluate the demographic effects of environmental variation (e.g. habitat change). 
Acknowledgements. We dedicate this paper to the memory of our dear colleague and co-author Markus Dyck, a polar bear biologist who was tragically killed in a helicopter accident in April 2021 during a polar bear survey in Lancaster Sound, Canada. Markus flew over 300 hours on Baffin Island collecting genetic biopsies from polar bears for this and other studies of the Baffin Bay subpopulation. He provided important contributions to the work of the Scientific Working Group, resulting in advice to the Canada-Greenland Joint Commission on Polar Bear on sustainable use of Baffin Bay and Kane Basin polar bears (SWG 2016). Markus was both a friend and colleague whose dedication to the conservation of polar bears will be long remembered. $\mathrm{He}$ will be greatly missed by us all. We thank M. Akeeagok, D. Andriashek, A. Apak, I. Egede, C. Elverum, P. Frame, B. J. Hainnu, P. Hegelund, J. Jaypoody, M. Jensen, J. Kalliktee, R. Kautak, J. Kigutak, B. Koonoo, J. Kooneloosie, B. Koonoo, G. Koonoo, J. Kruse, K. K. Kruse, J. Kuksiak, R. Kullualik, J. Neely, J. Noble Jr., T. Petersen, A. J. Pitseolak, Qaernaq Nielsen, Timothæus Petersen, T. Ross, V. Sahanatien, H. C. Schmidt, G. Szor, and M. Therkelsen for assistance with field data collection. G. C. White reviewed our mark-recapture modeling approach and interpretations of the analysis. Benjamin Cohen assisted with maps. We thank pilots Sebastian Holst and Geir Akse from Air Greenland. Permits and authorizations to undertake this work were issued by: Danish Transport and Aviation Authority, Environment Canada National Wildlife Areas research permit (Nun-NWA-13-07), Greenland Aviation Authority, Greenland Department of Environment (Nuuk), Greenland Department of Fisheries, Hunting and Agriculture (DFHA), Greenland Department of Health, Greenland Home Rule Government, Government of Nunavut Wildlife Research Permits (2011-041, 2012-010, 2012-015, 2013-011，2013-0292014-007), Nunavut Impact Review Board screening (13YN017 - exemption from environmental assessment screening), Parks Canada Research and Collection Permit (ANP-2011-8533), Qikiqtani Inuit Association (authorization Q13X009 - permission to access Inuit-owned lands). The Animal Use and Care Committee at the University of Minnesota (Protocol number 140331404A), and the relevant Greenland wildlife, environment, and veterinarian authorities approved the methods used in our research (the Greenland Government's Department of Fishery, Hunting and Agriculture protocol number: 2012060324. Document number: 807844). Financial, logistical, and in-kind support were provided by Air Greenland, Applied Physics Laboratory (University of Washington), Avannaa Resources Inc. (Copenhagen), Niels Berthelsen (Upenavik), Bureau of Mineral and Petroleum (Nuuk), Canada Department of National Defense, Environment and Climate Change Canada, Environmental Protection Agency (Ministry of Environment and Food of Denmark) -DANCEA Programme, Government of Nunavut, Greenland Department of Fisheries, Hunting and Agriculture (DFHA), Greenland Institute of Natural Resources, Greenland Pharmaceutical Authority (Nuuk), the Hospital in Upernavik - Peqqik, KNAPK (Greenland Hunters and Fishermen Organization), Kullorsuaq School, Lasø ApS (Upernavik), Mitteqarfik airports in Qaarsut and Upernavik, the Mittimatalik Hunters and Trappers Organization, the National Aeronautical and Space Agency (NASA) Development and Testing of Potential Indicators for the National Climate Assessment program (grant NNX13AN28G), NASA Climate and Biological Response (grant NNX11A063G), the Namautaq Hunters and Trappers Organization, the Nativak Hunters and Trap- pers Organization, Nunavut Wildlife Management Board, Parks Canada Agency, Polar Continental Shelf Project, Polar Science Center (University of Washington), Qaanaap Kommunia, Qikiqtaaluk Corporation, Quantum Murray LP, School of Aquatic and Fishery Sciences (University of Washington), Thule Air Force Base (Base Commander, US Air Force and Danish Liaison Officer, Danish Navy), Universal Helicopters, University of Oslo, Upernavik Seafood, Uummannaq Sundhedscenter - Peqqik, Vetlesen Foundation, and World Wildlife Fund. Two reviewers improved the manuscript.

\section{LITERATURE CITED}

Aars J, Marques TA, Buckland ST, Andersen M, Belikov S, Boltunov A, Wiig Ø (2009) Estimating the Barents Sea polar bear subpopulation size. Mar Mamm Sci 25:35-52

* Aars J, Marques TA, Lone K, Andersen M and others (2017) Polar bear population structure and trend in the western Barents Sea. Polar Res 36:1374125

Anon (2018) Selvstyrets bekendtgørelse nr. 3 af 14. september 2018 om fangst og beskyttelse af isbjørne (The Greenland Self Governance's executive order number 3 of 14 September 2018 on hunting and protection of polar bears). https://lovgivning.gl/da-DK/Lov?rid=\% 7BFFE266 56-F169-4242-A217-19DD318637DC\%7D (in Danish and Greenlandic)

Atkinson S, Born EW, Laidre KL (2011) A research plan for re-assessment of the Baffin Bay and Kane Basin polar bear sub-populations. Submitted to the Canada-Greenland Joint Commission on Polar Bear on July 21, 2011. Greenland Institute of Natural Resources, Nuuk

Atwood T, Marcot BG, Douglas DC, Amstrup SC, Rode KD, Durner GM, Bromaghin JE (2015) Evaluating and ranking threats to the long-term persistence of polar bears. Open-File Report 2014-1254. US Geological Survey, Reston, VA

*Bechshøft TØ, Sonne C, Dietz R, Born EW, Novak MA, Henchey E, Meyer JS (2011) Cortisol levels in hair of East Greenland polar bears. Sci Total Environ 409: 831-834

Boersen MR, Clark JD, King TL (2003) Estimating black bear population density and genetic diversity at Tensas River, Louisiana using microsatellite DNA markers. Wildl Soc Bull 31:197-207

Bolker BM (2016) Ecological models and data in R. Princeton University Press, Princeton, NJ

Born EW (1995) Status of the polar bear in Greenland. In: Wiig $\varnothing$, Born EW, Garner G (eds) Polar bears. Proceedings of the $11^{\text {th }}$ working meeting of the IUCN/SCC Polar Bear Specialist Group. IUCN, Gland, p 81-103

Born EW, Dietz R (2009) Polar bear Ursus maritimus. In: Boertmann D, Mosbech A, Schiedek D, Johansen K (eds) The eastern Baffin Bay. A preliminary strategic environmental impact assessment of hydrocarbon activities in the KANUMAS West area. NERI Technical Report no. 720. National Environmental Research Institute, Rønde, p 81-88. https://www2.dmu.dk/Pub/FR720.pdf

Born EW, Heilmann A, Holm LK, Laidre KL (2011a) Polar bears in Northwest Greenland: an interview survey about the catch and the climate. Monographs on Greenland, Man and Society, Vol 41. Museum Tusculanum Press, University of Copenhagen, Copenhagen

Born EW, Laidre K, Dietz R, Wiig Ø (2011b) The April 2009-April 2010 study of polar bear movement and habitat use in Northwest Greenland. In: Boertmann D, Mos- 
bech A (eds) Eastern Baffin Bay-a strategic environmental impact assessment of hydrocarbon activities. Scientific Report from Danish Centre for Environment and Energy No. 9. Aarhus University, Rønde, p 104-106. https://www2.dmu.dk/Pub/SR9.pdf

Born EW, Laidre K, Dietz R, Wiig Ø (2013) Box 8. The April 2009-April 2010 study of polar bear movements and habitat use in NW Greenland. In: Boertmann D, Mosbech A, Schiedek D, Dünweber M (eds) Disko West. A strategic environmental impact assessment of hydrocarbon activities. Scientific Report from Danish Centre for Environment and Energy No. 71. Aarhus University, Rønde, p 113-118. https://dce2.au.dk/pub/SR71.pdf

Boulanger J, Himmer S, Swan C (2004) Monitoring of grizzly bear population trends and demography using DNA mark-recapture methods in the Owikeno Lake area of British Columbia. Can J Zool 82:1267-1277

Bromaghin JF, McDonald TL, Amstrup SC (2013) Plausible combinations: an improved method to evaluate the covariate structure of Cormack-Jolly-Seber mark-recapture models. Open J Ecol 3:11-22

* Bromaghin JF, McDonald TL, Stirling I, Derocher AE and others (2015) Polar bear population dynamics in the southern Beaufort Sea during a period of sea ice decline. Ecol Appl 25:634-651

Burnham KP (1993) A theory for combined analysis of ring recovery and recapture data. In: Lebreton JD, North PM (eds) Marked individuals in the study of bird populations. Birkhauser-Verlag, Basel, p 199-213

Burnham KP, Anderson DR (2002) Model selection and multimodel inference: a practical information-theoretic approach. Springer, New York, NY

Calvert W, Ramsay M (1998) Evaluation of age determination of polar bears by counts of cementum growth layer groups. Ursus 10:449-453

Converse SJ, Kendall WL, Doherty PF, Naughton MB, Hines JE (2009) A traditional and a less-invasive robust design: choices in optimizing effort allocation for seabird population studies. In: Thomson DL, Cooch EG, Conroy MJ (eds) Modeling demographic processes in marked populations. Springer, New York, NY, p 727-744

Cooch EG, White GW (2015) Program MARK: a gentle introduction, $14^{\text {th }}$ edn. Colorado State University, Fort Collins, $\mathrm{CO}$

Dowsley M (2005) Inuit knowledge regarding climate change and the Baffin Bay polar bear population. Final Wildlife Report No. 1. Government of Nunavut, Iqaluit

Dowsley M (2007) Inuit perspectives on polar bears (Ursus maritimus) and climate change in Baffin Bay, Nunavut, Canada. Res Pract Soc Sci 2:53-74

Durner GM, Laidre KL, York GS (eds) (2018) Polar bears: Proc $18^{\text {th }}$ working meeting of the IUCN/SSC Polar Bear Specialist Group. IUCN, Gland

Dyck M, Campbell M, Lee D, Boulanger J, Hedman D (2017) 2016 aerial survey of the Western Hudson Bay polar bear subpopulation, final report. Government of Nunavut, Department of Environment, Wildlife Research Section, Igloolik. https://gov.nu.ca/sites/default/files/pb_wh_2016 _population_assessment_gn_report_27_june_2017.pdf

* Escajeda E, Laidre KL, Born EW, Wiig Ø and others (2018) Identifying shifts in maternity den phenology and habitat characteristics of polar bears (Ursus maritimus) in Baffin Bay and Kane Basin. Polar Biol 41:87-100

Ferguson SH, Taylor MK, Messier F (1997) Space use of polar bears in and around Auyuittuq National Park,
Northwest Territories, during the ice-free period. Can J Zool 75:1585-1594

Ferguson $\mathrm{SH}$, Taylor MK, Born EW, Rosing-Asvid A, Messier F (1999) Determinants of home range size for polar bears (Ursus maritimus). Ecol Lett 2:311-318

FFerguson SH, Taylor MK, Messier F (2000) The influence of sea ice dynamics on habitat selection by polar bears. Ecology 81:761-772

Fletcher D, Lebreton JD, Marescot L, Schaub M, Gimenez O, Dawson S, Slooten E (2012) Bias in estimation of adult survival and asymptotic population growth rate caused by undetected capture heterogeneity. Methods Ecol Evol 3:206-216

Galicia MP, Thiemann GW, Dyck MG, Ferguson SH (2015) Characterization of polar bear (Ursus maritimus) diets in the Canadian High Arctic. Polar Biol 38:1983-1992

* Herreman J, Peacock E (2013) Polar bear use of a persistent food subsidy: insights from non-invasive genetic sampling in Alaska. Ursus 24:148-163

Kendall KC, Stetz JB, Boulanger J, MacLeod AC, Paetkau D, White GC (2009) Demography and genetic structure of a recovering grizzly bear population. J Wildl Manag 73: 3-17

*Laidre KL, Born EW, Atkinson SN, Wiig $\varnothing$ and others (2018a) Range contraction and increasing isolation of a polar bear subpopulation in an era of sea ice loss. Ecol Evol 8:2062-2075

* Laidre KL, Stern H, Born EW, Heagerty P and others (2018b) Changes in winter and spring resource selection by polar bears Ursus maritimus in Baffin Bay over two decades of sea-ice loss. Endang Species Res 36:1-14

* Laidre KL, Atkinson S, Regehr EV, Stern HL and others (2020) Interrelated ecological impacts of climate change on an apex predator. Ecol Appl 30:e02071

* Lunn NJ, Servanty S, Regehr EV, Converse SJ, Richardson E, Stirling I (2016) Demography of an apex predator at the edge of its range-impacts of changing sea ice on polar bears in Hudson Bay. Ecol Appl 26:1302-1320

Meredith M, Sommerkorn M, Cassotta S, Derksen C and others (2019) Polar regions. In: Pörtner HO, Roberts DC, Masson-Delmotte V, Zhai P (eds) IPCC special report on the ocean and cryosphere in a changing climate. IPCC, Gland, p 203-320. https://www.ipcc.ch/srocc/

* Molnár PK, Bitz CM, Holland MM, Kay JE, Penk SR, Amstrup SC (2020) Fasting season length sets temporal limits for global polar bear persistence. Nat Clim Chang 10:732-738

Nichols JD, Hines JE, Pollock KH (1984) Effects of permanent trap response in capture probability on Jolly-Seber capture-recapture model estimates. J Wildl Manag 48: 289-294

Obbard ME, Stapleton S, Middel KR, Thibault I, Brodeur V, Jutras C (2015) Estimating the abundance of the Southern Hudson Bay polar bear subpopulation with aerial surveys. Polar Biol 38:1713-1725

\% Obbard ME, Cattet MRL, Howe EJ, Middel KR and others (2016) Trends in body condition in polar bears (Ursus maritimus) from the Southern Hudson Bay subpopulation in relation to changes in sea ice. Arctic Sci 2:15-32

Obbard ME, Stapleton S, Szor G, Middel KR, Jutras C, Dyck M (2018) Re-assessing abundance of Southern Hudson Bay polar bears by aerial survey: effects of climate change at the southern edge of the range. Arctic Sci 4: $634-655$

Paetkau D (2003) An empirical exploration of data quality in 
DNA-based population inventories. Mol Ecol 12: 1375-1387

Paetkau D, Amstrup SC, Born EW, Calvert W and others (1999) Genetic structure of the world's polar bear populations. Mol Ecol 8:1571-1584

Pagano AM, Peacock E, McKinney MA (2014) Remote biopsy darting and marking of polar bears. Mar Mamm Sci 30:169-183

* Pagano AM, Durner GM, Rode KD, Atwood TC and others (2018) High-energy, high-fat lifestyle challenges an Arctic apex predator, the polar bear. Science 359:568-572

* Palsbøll PJ, Allen J, Bérube M, Clapham PJ and others (1997) Genetic tagging of humpback whales. Nature 388:767-769

Patyk KA, Duncan C, Nol P, Sonne C and others (2015) Establishing a definition of polar bear (Ursus maritimus) health: a guide to research and management activities. Sci Total Environ 514:371-378

PBSG (Polar Bear Specialist Group) (1998) Status of the polar bear. In: Derocher AE, Garner GW, Lunn NJ, Wiig $\varnothing$ (eds) Polar bears: Proc $12^{\text {th }}$ working meeting of the IUCN/SSC Polar Bear Specialist Group. IUCN, Gland, p 23-44

PBSG (2010) 2009 status report on the world's polar bear subpopulations. In: Obbard ME, Thiemann GW, Peacock E, DeBruyn TD (eds) Polar bears: Proc $15^{\text {th }}$ working meeting of the IUCN/SSC Polar Bear Specialist Group. IUCN, Gland, p 31-80. http://pbsg.npolar.no/en/status/ status-table.html (accessed 4 May 2016)

* Peacock E, Laake J, Laidre KL, Born EW, Atkinson SN (2012) The utility of harvest recoveries of marked individuals to assess polar bear (Ursus maritimus) survival. Arctic 65:391-400

Peacock E, Taylor MK, Laake J, Stirling I (2013) Population ecology of polar bears in Davis Strait, Canada and Greenland. J Wildl Manag 77:463-476

Peacock E, Sonsthagen SA, Obbard ME, Boltunov A and others (2015) Implications of the circumpolar genetic structure of polar bears for their conservation in a rapidly warming Arctic. PLOS ONE 10:e112021

Peñaloza CL, Kendall WL, Langtimm CA (2014) Reducing bias in survival under nonrandom temporary emigration. Ecol Appl 24:1155-1166

Pledger S, Efford M (1998) Correction of bias due to heterogeneous capture probability in capture-recapture studies of open populations. Biometrics 54:888-898

Pollock KH, Nichols JD, Brownie C, Hines JE (1990) Statistical inference for capture-recapture experiments. Wildl Monogr 107:3-97

Powell L (2007) Approximating variance of demographic parameters using the delta method: a reference for avian biologists. Condor 109:949-954

Pradel R (2009) The stakes of capture-recapture models with state uncertainty. In: Thomson DL, Cooch EG, Conroy MJ (eds) Modeling demographic processes in marked populations. Springer, New York, NY, p 781-795

R Development Core Team (2021) R: a language and environment for statistical computing. R Foundation for Statistical Computing, Vienna

Regehr EV, Lunn NJ, Amstrup SC, Stirling I (2007) Effects of earlier sea ice breakup on survival and population size of polar bears in western Hudson Bay. J Wildl Manag 71: 2673-2683

Regehr EV, Wilson RR, Rode KD, Runge MC (2015) Resilience and risk - a demographic model to inform conser- vation planning for polar bears. Open-File Report No. 2015-1029. US Geological Survey, Reston, VA

Regehr EV, Atkinson S, Born EW, Laidre KL, Lunn NJ, Wiig $\varnothing$ (2017) Harvest assessment for the Baffin Bay and Kane Basin polar bear subpopulations: final report to the Canada-Greenland Joint Commission on Polar Bear. Environment and Climate Change Canada, Ottawa, and Greenland Institute of Natural Resources, Nuuk

Regehr EV, Hostetter NJ, Wilson RR, Rode KD, St Martin M, Converse SJ (2018) Integrated population modeling provides the first empirical estimates of vital rates and abundance for polar bears in the Chukchi Sea. Sci Rep 8: 16780

Rode KD, Peacock E, Taylor M, Stirling I, Born EW, Laidre KL, Wiig $\varnothing ~(2012)$ A tale of two polar bear populations: ice habitat, harvest and body condition. Popul Ecol 54: 3-18

Kode KD, Regehr EV, Douglas DC, Durner G, Derocher AE, Thiemann GW, Budge SM (2014) Variation in the response of an Arctic top predator experiencing habitat loss: feeding and reproductive ecology of two polar bear populations. Glob Change Biol 20:76-88

Rode KD, Wilson RR, Douglas DC, Muhlenbruch V and others (2018) Spring fasting behavior in a marine apex predator provides an index of ecosystem productivity. Glob Change Biol 24:410-423

Schaub M, Gimenez O, Schmidt BR, Pradel R (2004) Estimating survival and temporary emigration in the multistate capture-recapture framework. Ecology 85: 2107-2113

Seber GAF (1982) The estimation of animal abundance and related parameters. MacMillan, New York, NY

Stapleton S, Atkinson S, Hedman D, Garshelis D (2014) Revisiting Western Hudson Bay: using aerial surveys to update polar bear abundance in a sentinel population. Biol Conserv 170:38-47

Stapleton S, Peacock E, Garshelis D (2016) Aerial surveys suggest long-term stability in the seasonally ice-free Foxe Basin (Nunavut) polar bear population. Mar Mamm Sci 32:181-201

Stern HL, Laidre KL (2016) Sea-ice indicators of polar bear habitat. Cryosphere 10:2027-2041

Stirling I, Derocher AE (2012) Effects of climate warming on polar bears: a review of the evidence. Glob Change Biol 18:2694-2706

SWG (Scientific Working Group to the Canada-Greenland Joint Commission on Polar Bear) (2016) Re-assessment of the Baffin Bay and Kane Basin polar bear subpopulations: final report to the Canada-Greenland Joint Commission on Polar Bear. Environment and Climate Change Canada, Ottawa, and Greenland Institute of Natural Resources, Nuuk

*Taylor MK, Lee J (1995) Distribution and abundance of Canadian polar bear populations: a management perspective. Arctic 48:147-154

* Taylor MK, Akeeagok S, Andriashek D, Barbour W and others (2001) Delineating Canadian and Greenland polar bear (Ursus maritimus) populations by cluster analysis of movements. Can J Zool 79:690-709

Taylor MK, Laake J, McLoughlin PD, Born EW and others (2005) Demography and viability of a hunted population of polar bears. Arctic 58:203-214

White GC, Burnham KP (1999) Program MARK: survival estimation from populations of marked animals. Bird Study 46:S120-S139 
White GC, Cooch EG (2017) Population abundance estimation with heterogeneous encounter probabilities using numerical integration. J Wildl Manag 81:322-336

Whiteman JP, Harlow HJ, Durner GM, Anderson-Sprecher $\mathrm{R}$ and others (2015) Summer declines in activity and body temperature offer polar bears limited energy savings. Science 349:295-298

Editorial responsibility: Mike Bruford, Cardiff, UK

Reviewed by: 2 anonymous referees
Williams BK, Nichols JD, Conroy MJ (2002) Analysis and management of animal populations. Academic Press, San Diego, CA

KYork J, Dowsley M, Cornwell A, Kuc M, Taylor M (2016) Demographic and traditional knowledge perspectives on the current status of Canadian polar bear subpopulations. Ecol Evol 6:2897-2924

Submitted: March 15, 2021

Accepted: July 16, 2021

Proofs received from author(s): October 1, 2021 